\title{
Access to cigarettes among the youths in seven South-East Asian countries
}

\author{
Nancy Satpathy', Pratap K. Jena², Venkatarao Epari', Jugal Kishore ${ }^{3}$
}

\section{Dear Editor,}

The global tobacco epidemic kills about eight million people annually ${ }^{1}$. In many countries, cigarettes are the most commonly used tobacco product and most smokers start cigarette smoking when they are still minors. Nearly 9 in 10 cigarette smokers try their first cigarette before the age of 18 years $^{2}$. Evidence shows that adult smokers with less intentions to quit have a history of initiating smoking in their adolescence ${ }^{3}$.

The key component of a comprehensive tobacco control program involves restricting the supply of and demand for tobacco products to discourage youths and young adults from initiating smoking. This is an obligation of Parties signatory to the WHO Framework Convention on Tobacco Control (FCTC). Every nation from South-East Asia (SEA), except Indonesia, has signed and ratified the WHO FCTC. However, the enforcement of compliant FGTC comprehensive tobacco legislation differs from country to country. Indonesia is a country that is neither a signatory nor a party to the FCTC ${ }^{4,5}$.

Global Youth Tobacco Survey (GYTS) data have indicated that the methods for physical access to cigarettes vary across the SEA region. Buying them from a store, shop or on the street, followed by other sources, were the preferred methods of obtaining cigarettes among boys in all countries, except for East Timor where buying from vending machines was the most way to purchase cigarettes. Similarly, the preferred methods of getting cigarettes among girls were the other sources followed by shops, kiosks or on the street sales, except for East Timor where vending machines followed by shops or kiosks were the preferred way to obtain cigarettes ${ }^{2}$.

In all countries except Indonesia, the weekly pocket money was insufficient to buy a cigarette packet having 20 cigarettes, for the majority of students. In Bhutan, East Timor, and Indonesia where girls' cigarette smoking was $>2 \%$, financial access among girls was higher than for boys. Among the seven SEA countries, except Indonesia, all had ratified the WHO FCTC during 2003 and 2004. The countries brought in to force their tobacco control legislation along with school tobacco control policy during the period 2005-2017, while GYTS was implemented during 2013-16. At the time of GYTS, East Timor and Thailand had no tobacco control legislation including the ban on tobacco sales to or by minors and by vending machines (Table 1). Despite restrictions on tobacco sales to minors in other countries, in the majority of instances vendors supplied cigarettes to the students, which was highest for Bangladeshi boys and Indonesian girls.

Restricting access and age restrictions on tobacco product sales have been enforced in many countries with varying success, due to resource constraints that inhibit implementing these laws. A less obvious reason may be the subtle impression created by the law that consumption of tobacco is an adult
AFFILIATION

1 Department of Community Medicine, Institute of Medical Sciences, Sum Hospital, Sikhsha 'O' Anusandhan University, Bhubaneswar, India 2 KIIT School of Public Health, Kalinga Institute of Industrial Technology, Bhubaneswar, India 3 Department Community Medicine, Vardhman Mahavir Medical College and Safdarjung Hospital, Delhi University, New Delhi, India

\section{CORRESPONDENCE TO}

Pratap K. Jena. KIIT School of Public Health, Kalinga Institute of Industrial Technology, Bhubaneswar, 751024, Odisha, India. E-mail: drpratapjena@ gmail.com ORCID ID: https://orcid. org/0000-0002-1236-3103

KEYWORDS

GYTS, access, youth, cigarettes, FCTC Article 15, South-East Asian

Received: 23 November 2020 Revised: 25 January 2021 Accepted: 27 January 2021 
Table 1. Tobacco control (TC) policy environment for tobacco use restriction among minors in WHO SEA countries

\begin{tabular}{llccc} 
Country (GYTS Year) & WHO FCTC Ratification Date & $\begin{array}{c}\text { First TC Law \& } \\
\text { School TC Policy }\end{array}$ & $\begin{array}{c}\text { Legal age for sale or } \\
\text { purchase of tobacco } \\
\text { (years) }\end{array}$ & $\begin{array}{c}\text { Prohibition of sales } \\
\text { to or by minors \& } \\
\text { by tobacco vending machines }\end{array}$ \\
\hline Bangladesh (2013) & 14 June 2004 & 2005 & 18 & 2005 \\
Bhutan (2013) & 23 August 2004 & 2010 & 18 & 2010 \\
East Timor (2013) & 22 December 2004 & 2016 & 17 & 2016 \\
Indonesia (2014) & - & 2009 & 18 & 2012 \\
Myanmar (2016) & 21 April 2004 & 2006 & 18 & 2006 \\
Sri Lanka (2015) & 11 November 2003 & 2006 & 21 & 2015 \\
Thailand (2015) & 8 November 2004 & 2017 & 18 & 2017
\end{tabular}

habit, thus increasing its glamour among youth. Consequently, any publicity or intervention to implement the law may result in increased demand by the younger age groups for tobacco products ${ }^{6}$. Forbidding self-service displays and vending machines is seen as a more efficient and realistic measure to minimize access to tobacco products among the youth. It was also recommended that the advertising of tobacco products at the pointof-sale be prohibited as these displays may be used as a promotional tactic as well as a 'reminder' for consumers to purchase or use tobacco ${ }^{7}$. Another action that falls within the scope of limiting access is the response to new types of tobacco products that come on the market. Therefore, one proactive step may be to prohibit the introduction of new forms of tobacco products.

Evidence suggests that intervention such as limiting access to tobacco products can be successfully implemented only if comprehensive tobacco control measures such as taxation, health warnings, bans etc., are in place ${ }^{8}$. Understanding how and where youths have access to cigarettes can help in devising effective tobacco control strategies. Access to cigarettes among youths is very contextual, can defy legal provisions and financial affordability. Comprehensive tobacco control strategies aimed at restricting youths' access to tobacco products may be viewed in the context of country-specific socialcultural, economic, and legal environments ${ }^{9}$.

\section{REFERENCES}

1. Centers for Disease Control and Prevention. Global
Tobacco Surveillance System Data. https://nccd.cdc. gov/GTSSDataSurveyResources/Ancillary/DataReports. aspx?CAID=2. Accessed May 7, 2020.

2. Centers for Disease Control and Prevention. Youth and Tobacco Use: Youth use of tobacco products in any form is unsafe. https://www.cdc.gov/tobacco/data_statistics/ fact_sheets/youth_data/tobacco_use/index.htm. Accessed May 24, 2020.

3. Paavola M, Vartiainen E, Puska P. Smoking cessation between teenage years and adulthood. Health Educ Res. 2001;16(1):49-57. doi:10.1093/her/16.1.49

4. WHO Framework Convention on Tobacco Control. Article 16: Sales to and by minors reports. https:// untobaccocontrol.org/impldb/article-16/. Accessed May 29, 2019.

5. World Health Organization. WHO Framework Convention on Tobacco Control: guidelines for implementation Article 5.3; Article 8; Articles 9 and 10; Article 11; Article 12; Article 13; Article 14. Geneva, Switzerland: World Health Organization; 2013. https://apps.who.int/iris/ bitstream/handle/10665/80510/9789241505185_ eng.pdf;jsessionid=82D1C1150EB1F0419103ED 45 78AF59F1? sequence=1. Accessed June 4, 2020.

6. World Health Organization. 2018 Global progress report on implementation of the WHO Framework Convention on Tobacco Control. Geneva, Switzerland: World Health Organization; 2018. https://www.who.int/fctc/reporting/ WHO-FCTC-2018_global_progress_report.pdf. Accessed May 29, 2019.

7. U.S. Department of Health and Human Services. Preventing Tobacco Use Among Youth and Young Adults: A Report of the Surgeon General. Atlanta, GA: U.S. Department of Health and Human Services, Centers for Disease Control and Prevention, National Center for Chronic Disease Prevention and Health Promotion, Office on Smoking and Health; 2012. https://www.ncbi.nlm.nih. gov/books/NBK99237/pdf/Bookshelf_NBK99237.pdf. Accessed May 7, 2020. 
8. International Agency for Research on Cancer, World Health Organization. Methods for Evaluating Tobacco Control Policies. In: IARC Handbooks of Cancer Prevention; vol 1. https://www.iarc.who.int/wp-content/ uploads/2018/07/Tobacco_vol12.pdf. Accessed June 3, 2020.

9. World Health Organization. WHO report on the global tobacco epidemic 2019: offer help to quit tobacco use. https://www.who.int/teams/health-promotion/ tobacco-control/who-report-on-the-global-tobaccoepidemic-2019. Accessed May 7, 2020. eff.

CONFLICTS OF INTEREST

The authors have completed and submitted the ICMJE Form for Disclosure of Potential Conflicts of Interest and none was reported.

FUNDING

There was no source of funding for this research.

PROVENANCE AND PEER REVIEW

Not commissioned; internally peer reviewed. 